\title{
DOI: 10.22616/j.balticsurveying.2020.005 \\ STUDY OF THE RELATIONSHIP BETWEEN ABANDONED LAND AND DIFFERENT INDICATORS
}

\author{
(iD) Puziene Ruta ${ }^{1}$, Anikeniene Asta ${ }^{2}$ \\ ${ }^{1}$ Vytautas Magnus University Agriculture Academy (Lithuania) \\ ${ }^{2}$ Vilnius College of Technologies and Design (Lithuania)
}

\begin{abstract}
One of the most pressing problems in land management is abandoned agricultural land. Abandoned land in Lithuania is unattended and not used for agricultural activities. These areas degrade the country's landscape and over time overgrow with shrubs or low-value plants. The article analyzes the change of abandoned agricultural land in 2015-2019. State control to reduce abandoned land is discussed. Relations with selected indicators are analyzed. Data visualization was performed with ArcGIS software.

However from 2015 to 2019, a constant decrease of abandoned land has occurred. The analysis showed that the majority of abandoned land is found in Vilnius, Utena and Alytus counties. The results of the correlation analysis showed the highest dependence of abandoned lands on the average performance score in counties.

Key words: abandoned land, average performance score, population rate, statistical analysis
\end{abstract}

\section{Introduction}

All the land in the territory of the Republic of Lithuania is a state asset, therefore, it is particularly important to ensure a proper and rational land use. As a result, provisions, methodological instructions, laws and Government-issued resolutions have been enshrined in law on the basis of which the land protection is carried out. In accordance with the resolution No. 1244 "On the Approval of the Provisions of the State Control of Land Use" issued by the Government of the Republic of Lithuania on 1994-12-12, the state is obliged to ensure a proper and rational use of land (as a resource). The National Land Service under the Ministry of Agriculture organizes and performs the state control of land use (Resolution of the Government of the Republic of Lithuania..., 1994).

According to the newest data from the Centre of Registers, currently, there are almost 60.6 thousand recorded abandoned agricultural land plots (hereinafter referred to as AL) in the entire country, that cover 34.8 thousand hectares (ha) or 0.6 percent of the country's entire territory (www.delfi.lt, 2019).

In accordance with Article 2 of the Law on Land Tax of the Republic of Lithuania, "the Abandoned Agricultural Land shall mean the areas of agricultural land in a land parcel or any part thereof covered with woody plants (except for plantations) identified by remote cartographic methods in accordance with the procedure established by the Government of the Republic of Lithuania or an authority authorised thereby" (Law of the Republic of Lithuania..., 2011). V. Daugaliene states that "during the last thirty years, the area of cultivated land has decreased in many EU countries, and the reason for it is the abandoned agricultural land. The land abandonment is only a consequence of social and economic issues in rural areas. A short abandonment period for intensively cultivated land is useful due to the decrease in the pollution caused by agricultural activities. However, the abandonment of former often botanically rich meadows causes a great harm to biodiversity. Due to these reasons, the land abandonment causes a growing concern among people who make the decisions on both national and EU levels" (Daugalienè, 2019). Abandoned land plots distort the landscape, negatively affect the development of the national agriculture, complicate the resource management (Kuliešis, Šalengaite, 2010).

The state control of land use aims at ensuring the land management and use in compliance with the requirements of the Law on Land of the Republic of Lithuania and other laws regulating the supervision of the land use. The National Land Service (NLS) is planning to carry out 12 thousand state land control checks this year. 60 percent of checks are anticipated to be scheduled, and the remaining ones - unscheduled: on the basis of received complaints and requests, or follow-up checks aimed at checking whether previously identified violations have been eliminated (National Land Service under the Ministry of Agriculture ${ }^{\mathrm{a}}$, 2019). In 2019, the following objectives were set: to tighten the state control of the land use over territories with the most recorded abandoned (state and private) land; to tighten the state control of the land use over the leased state land, whose purpose is "for other uses", use and the control of the use of land plots transferred free of charge to municipalities for use managed by the right of use. A particular attention will be allocated to the use of land plots 
located in the state border protection zone (National Land Service under the Ministry of Agriculture 2019).

The NLS director Laimonas Čiakas stressed that "the analysis of the 2018 data provided by the state control of land use revealed that the majority of violations are identified when land plots are abandoned, unmanaged and uncultivated. Still, a significant share of owners and users of a land do not properly manage and use their land. Laimonas Čiakas noted that the amount of state control checks of the land use performed in 2018 exceeded the planned amount and constituted 105.79 percent of the checks scheduled in the NLS plan of land management works" (National Land Service under the Ministry of Agriculture ${ }^{\mathrm{a}}$, 2019).

In order to decrease the amount of abandoned agricultural land areas, an order of the Minister of Agriculture of the Republic of Lithuania (on the approval of the Abandoned Land Program) was approved (2011 years Decemberer for agricultural or other activity to be performed there. Tasks of the program: to include the abandoned land into the state land accounting; to accelerate agricultural land market processes; to create preconditions for more rational land use; to create preconditions for alternative land use; to create better conditions for the development of animal husbandry on abandoned land; to initiate studies of changes in the land condition in accordance with the extent and period of abandonment (Order of the Minister of Agriculture of the Republic of Lithuania..., 2011).

The aim of the paper: to analyse the change in abandoned agricultural land of the Republic of Lithuania and its dependency on various factors.

The tasks of the study:

1. To analyse the distribution of abandoned agricultural land areas on the territory of Lithuania and to assess its change during the 2015-2019 period.

2. To analyse the dependency of the abandoned land on various parameters.

The subject of the research is abandoned agricultural land areas.

\section{Methodology of research and materials.}

In order to determine and assess the change in abandoned agricultural land using the 2017-2018 satellite photos and taking into account notes provided by landowners and other persons, the collection of the spatial data AŽ_DRLT of abandoned land of the Republic of Lithuania was updated in 2018. The data (AŽ_DRLT) is used for calculating the land tax for abandoned agricultural land. The critical tolerance of the graphic accuracy of AŽ_DRLT objects is no more than $8 \mathrm{~m}$. This dataset was used for research.

On the basis of the analysis of the 2015-2019 data of the NLS land fund under the Ministry of Agriculture of the Republic of Lithuania and the data from the Land Information System (LIS), a distribution map of abandoned agricultural land was compiled (Figure 1).

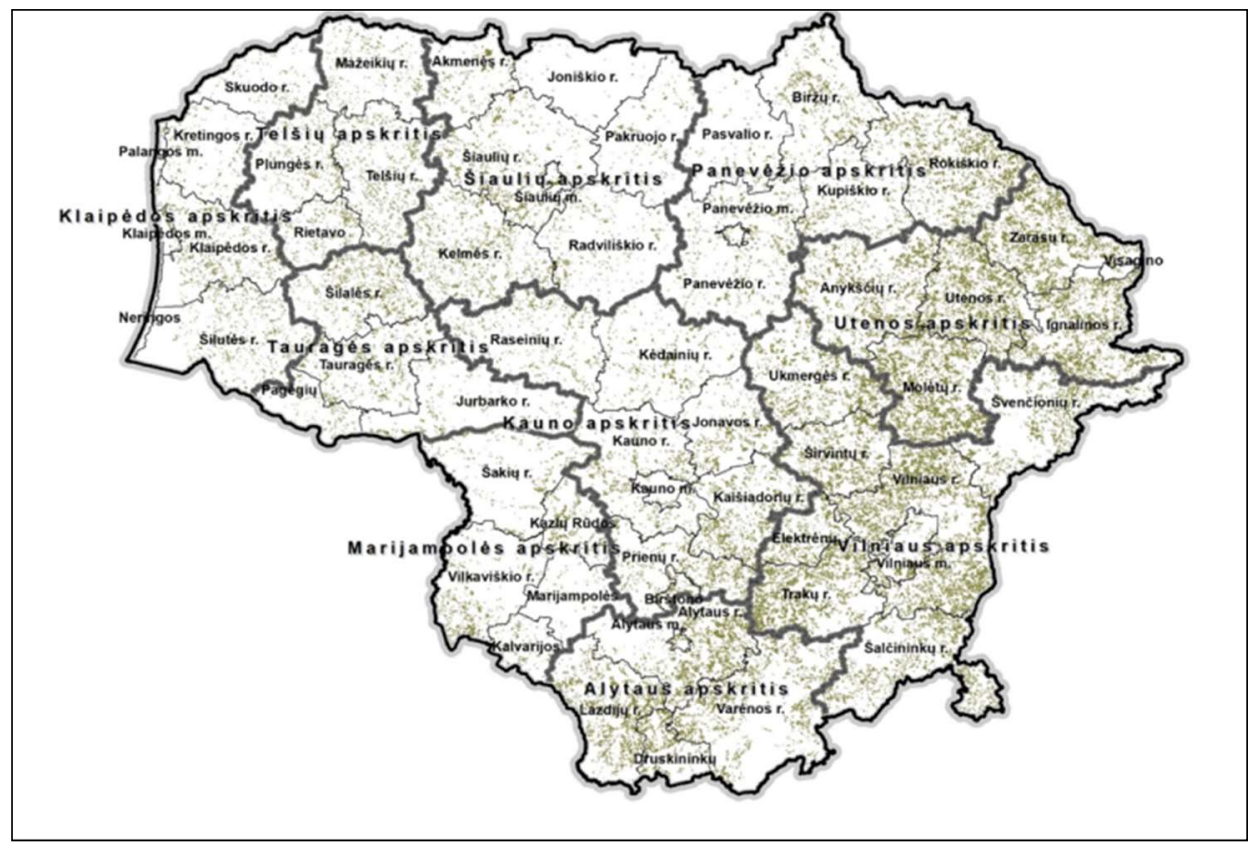

Fig. 1. Distribution map of abandoned land in the Republic of Lithuania 
A study of links between the selected criteria is conducted using a correlation analysis. The correlation analysis has been conducted between these parameters (1):

1. percentage of AL area to the county area (2019 year) $\left(r_{1}\right)$,

2. average performance score in counties $\left(\mathrm{r}_{2}\right)$,

3. population rate in counties $\left(\mathrm{r}_{3}\right)$.

Coeficient of correlation:

$\mathrm{x}, \mathrm{y}-$ variable

$$
r=\frac{\overline{x y}-\bar{x} \cdot \bar{y}}{\sqrt{x^{2}-\left(\bar{x}^{2}\right)} \sqrt{y^{2}-\left(\bar{y}^{2}\right)}}
$$

\section{Discussions and results}

\subsection{Change in Abandoned Agricultural Land in 2015-2019}

As of 1 July 2018, there were 57.1 thousand ha of abandoned agricultural land, which is about 1.7 percent of the total agricultural land area. For comparison, as of 1 July 2017, there were 63.2 thousand ha of abandoned agricultural land, which is about 1.9 percent of the total agricultural land area (National Land Service under the Ministry of Agriculture ${ }^{\mathrm{b}}$, 2019).

Figure 1 reveals that the main spread of abandoned land is in Utena, Vilnius and Alytus counties. Furthermore, Telsiai county and a part of Taurage and Siauliai counties stand out in the Western Lithuania. In accordance with the available data, the analysis of AL areas was conducted.

The analysis of the change in AL areas in counties during different periods reveals that the tendencies remain the same as can be seen in the map provided in Figure 1 (Figure 2).

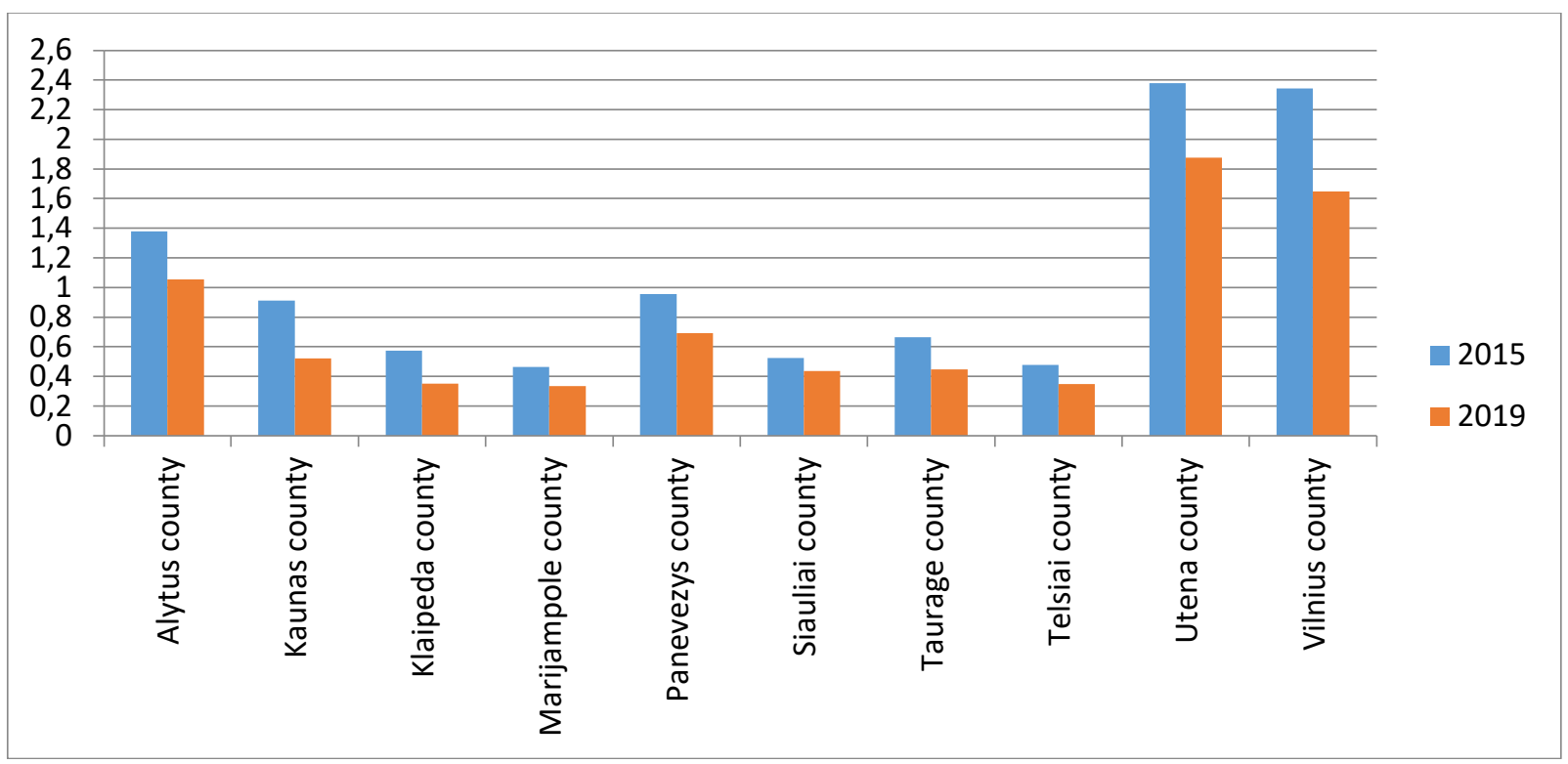

Fig. 2. Percentage of the abandoned land area to the total area of counties

In Figure 2, the share of abandoned land in percent to the total area in counties in 2015 and 2019 is depicted. The highest percentage is found in Vilnius, Utena and Alytus counties - from 2.4 to 1.4 percent in 2015 and from 1.9 to 1.1 percent in 2019. It is not a low percentage, because it was estimated on the basis of the total area, without subtracting forest and other land areas. The lowest percentage is in Telsiai, Marijampole, Klaipeda and Siauliai counties. As can be seen from Figure 1, some districts have larger abandoned land areas than are found in the rest of the districts constituting the same county.

The comparison of diagrams provided in Figure 2 reveals that there is a change in AL areas during 2015-2019; there is a visually observed decrease, especially in Vilnius and Panevezys counties. The change in abandoned land (in hectares) in counties during the period of 2015-2019 was performed as well, which is demonstrated in Figure 3. Moreover, the AL area decrease rate, i.e. by how many ha did $\mathrm{AL}$ areas in the counties decreased per year. 


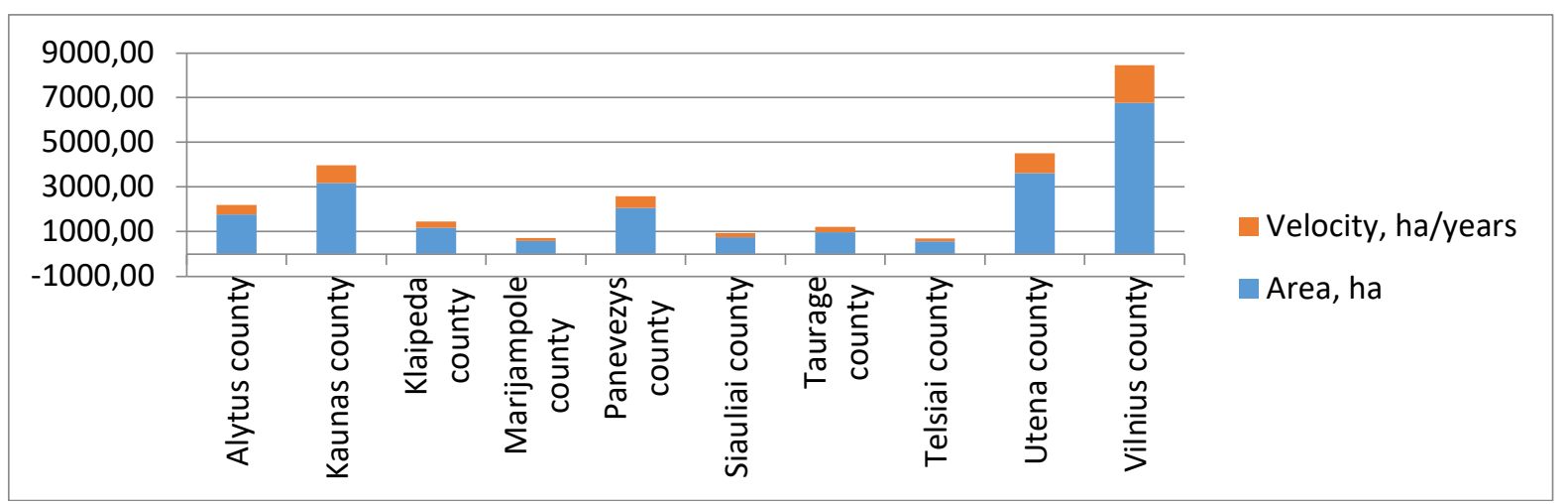

Fig. 3. Decrease of abandoned land in counties, ha

As can be seen from Figure 3, the largest decrease in abandoned land area during the studied period occurred in Vilnius (6769 ha), Utena (3611 ha), Kaunas (3176 ha) and Panevezys (2070 ha) counties. Correspondingly, the decrease rate of the areas was: 1,692, 902, 794, $517 \mathrm{ha} /$ year. The results of the study (Figures 2, 3) show that the greatest decrease in abandoned land is not necessarily related to the largest abandoned land area in the county. Kaunas and Panevezys counties did not have so many AL areas as Alytus county, but these counties outperformed the latter in terms of AL decrease rate.

\subsection{Links Between Abandoned Land and Selected Parameters}

The density of abandoned land is affected by the performance score of the agricultural land (Kuliešis, Šalengaite, 2010, Aleknavičius, 2007). The performance score is determined by the soil typology of agricultural land, its granulometric composition, the land reclamation state, moisture, the soil cover diversity, stoniness, agrochemical properties, climatic conditions and a basic score.

In accordance with the soil productivity results (Order of the Minister of Agriculture of the Republic of Lithuania..., 2007), the soil is divided into 5 groups (types). I soil group - dominated by the soil of a very good economic value (47.1-52.0 points). II soil group - dominated by the soil of a good economic value (42.1-47.0 points), III soil group - dominated by the soil of a medium economic value (37.0-42.0 points); IV soil group - mostly dominated by the soil of a relatively poor economic value (32.1-37,1 points). V soil group - dominated by the soil of a poor economic value (27.1-32.0 points) (Mažvila, Lukšienè, Staugaitis, Mockevičius, 2015).

The relation between the population rate and the abandoned land was analysed by XX (Rybokas, 2011; Kuliešis and Šalengaitè, 2010).

The application of statistical methods allows determining links between studied parameters. A statement that the abandoned land area depends on the performance score and the population rate is encountered in works of many authors. During the study conducted hereby, the links between these criteria considered in the works by other authors as well and AL area counties.

While using the aforementioned studies conducted by other authors, no statistical analysis methods were employed. Therefore, the results of the correlation analysis between the selected criteria and AL areas are provided herein.

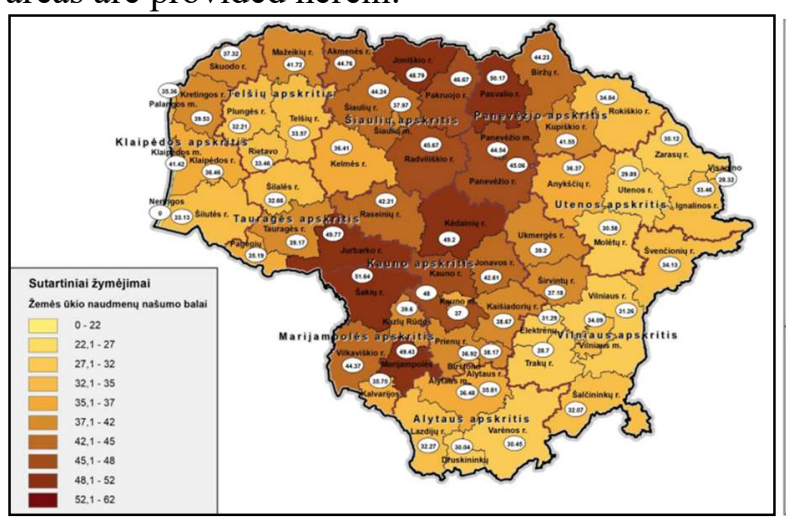

a)

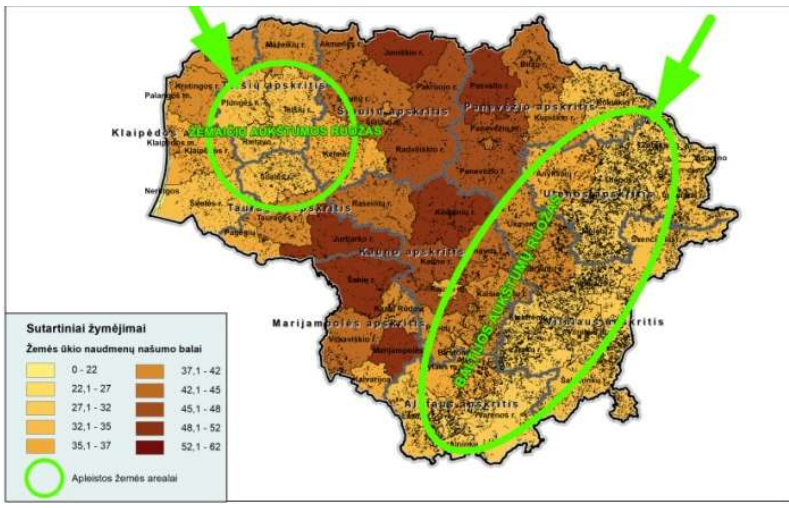

b)

Fig. 4. Maps: a) The point assessment of agricultural land, b) The distribution of abandoned land areas in counties 
Firstly, by using maps compiled by the authors, a visual assessment of the distribution of AL areas has been conducted, and it has been compared to the performance score map (Figure 4).

The visual comparison of maps reveals the correspondence of the distribution of AL areas with the distribution of the land performance score in Lithuania. It is evident, that, in the Zemaitija Upland dominated by land areas with a poorer performance, AL areas are correspondingly larger. The same could be said regarding a stretch of land in the eastern Lithuania with a low performance: the distribution of a stretch of abandoned land areas is similar.

A study of links between the selected criteria is conducted using a correlation analysis. The obtained result is provided in Table 1 .

The results of the correlation analysis

Table 1.

\begin{tabular}{|c|c|c|c|}
\hline Correlation coeficients & $\mathbf{r}_{\mathbf{1}}$ & $\mathbf{r}_{\mathbf{2}}$ & $\mathbf{r}_{\mathbf{3}}$ \\
\hline $\mathbf{r}_{\mathbf{1}}$ & 1 & - & - \\
\hline $\mathbf{r}_{\mathbf{2}}$ & $-0,68$ & 1 & - \\
\hline $\mathbf{r}_{\mathbf{3}}$ & 0,41 & $-0,07$ & 1 \\
\hline
\end{tabular}

As can be seen from the results in Table 1, the correlation link between the performance score and the population rate is insignificant; therefore, these criteria may be considered unrelated. A rather significant negative correlation link is obtained between AL areas and the performance score $(-0,68)$. Therefore, due to it, it can be stated that while the performance score increases, the abandoned land area decreases. Meanwhile, the population rate and the AL area in counties are linked by a significantly weaker correlation when compared to the AL and the performance score. This correlation coefficient does not reach 0.5 , therefore, the causal relationship between these parameters is relatively doubtful.

\section{Conclusions}

Largest abandoned land areas in 2015-2019 in the Republic of Lithuania were distributed on the basis of the same tendencies. The majority of abandoned land is found in Vilnius, Utena and Alytus counties - from 2.4 to 1.4 percent (2015 year) and from 1.9 to 1.1 percent (2019 year) to the total area of counties.

From 2015 to 2019, a constant decrease of abandoned land had occurred. The most significant decrease is observed in Vilnius (6769 ha), Utena (3611 ha), Kaunas (3176 ha) and Panevezys (2070 ha) counties. The decrease rate of these areas reached correspondingly 1,692, 902, 794 and 517 ha per year. The highest and lowest change in these land areas during the selected period partially corresponds to the amount of these areas in counties. However, some counties stand out - in Kaunas and Panevezys counties, a more significant decrease in $\mathrm{AL}$ areas than their relative amount in comparison to other counties is observed.

The correlation analysis revealed a relatively high negative dependency $(-0.68)$ between the point assessment abandoned and agricultural land areas. And the dependency between the population rate in counties and $\mathrm{AL}$ areas is doubtful: a coefficient less than 0.5 was obtained during a correlation analysis, therefore, a statement that there is a link between these parameters would be inexpedient.

It is planned to carry out further investigations. Need to identify more factors that determine the existence of the abandoned land.

\section{References}

1. Aleknavičius, P. (2007). Kaimiškųjų teritorijų žemės naudojimo problemos (Land use problems in rural areas). Žemès ūkio mokslai, Volume 1, pp. 2424-4120, (in Lithuanian).

2. Daugalienė V. (2019). Europietiškas požiūris i apleistas žemes ir jų tvarkymo perspektyvas (European approach to brownfields and the prospects for their management). Viewed 20 september, 2019, (https://zum.lrv.lt/lt/naujienos/europietiskas-poziuris-i-apleistas-zemes-ir-ju-tvarkymo-perspektyvas), European approach to brownfields and prospects for their management), (in Lithuanian).

3. Kuliešis G., Šalengaitė D. (2010). Apleista žemè Lietuvoje: problemos, galimi sprendimo būdai, (Abandoned Land in Lithuania: Problems, Possible Solutions, Management theory and studies for rural business and infrastructure development), Volume 5, Issue 24, pp. 1822-6760, (in Lithuanian).

4. Lietuvos respublikos vyriausybès Nutarimas dèl žemès naudojimo valstybinès kontrolès nuostatų patvirtinimo, 1994 m. gruodžio 12 d. Nr. 1244. (Resolution of the Government of the Republic of Lithuania 
on the Approval of the Regulations for the State Control of Land Use, 1994. December 12 No. 1244). Viewed 27 december, 2019, (https://e-seimas.lrs.lt/portal/legalAct/lt/TAD/TAIS.15562/asr) (in Lithuanian).

5. Lietuvos respublikos žemès mokesčio ịstatymas (Law of the Republic of Lithuania on Land Tax), (2011). Consolidated edition of 2016-01-01 iki 2019-12-31, Nr. 163-7743. Viewed 28 september, 2019, (https://www.e-tar.lt/portal/lt/legalAct/TAR.D267FBDC094B/asr) (in Lithuanian).

6. Lietuvos respublikos Žemès ūkio ministro įsakymas Dèl apleistos žemés naudojimo programos patvirtinimo, $2011 \mathrm{~m}$. gruodžio $16 \mathrm{~d}$. Nr. 3D-925. (Order of the Minister of Agriculture of the Republic of Lithuania On Approval of the Abandoned Land Use Program, 2011 December 16), Viewed 20 september, 2019, (https://e-seimas.lrs.lt/portal/legalAct/lt/TAD/TAIS.416006?jfwid=rivwzvpvg) (in Lithuanian).

7. Lietuvos respublikos Žemès ūkio ministro įsakymas Dèl žemés našumo vertinimo atnaujinimo, $2007 \mathrm{~m}$. liepos 31 d. Nr. 3D-359 (Order of the Minister of Agriculture of the Republic of Lithuania Regarding the update of the assessment of land productivity, 2007 July 31 No. 3D-359),Viewed 20 september, 2019, (https://e-seimas.lrs.lt/portal/legalAct/lt/TAD/TAIS.302576?jfwid=191 fum803q), (in Lithuanian).

8. Mažvila J., Lukšienė L., Staugaitis G., Mockevičius R. (2015). Lietuvos žemių našumas, [Productivity of Lithuanian Lands], Mano ūkis, Volume 4, Viewed 23 december, 2019, (https://www.manoukis.lt/mano-ukiszurnalas/2015/04/lietuvos-zemiu-nasumas/), (in Lithuanian).

9. Nacionalinė žemės tarnyba prie Žemės ūkio ministerijos ${ }^{a},(2019)$. NŽT stiprins žemės naudojimo valstybinę kontrolę - apleistos žemès plotų patikrą (National Land Service under the Ministry of Agriculture ${ }^{\text {a }}$. The NLS will strengthen state control of land use - inspection of abandoned land) Viewed 28 december, 2019, (http://www.nzt.lt/go.php/lit/Nzt-stiprins-zemes-naudojimo-valstybine-kontrole--apleistos-zemes-plotupatikra), (in Lithuanian).

10. Nacionalinè žemès tarnyba prie Žemès ūkio ministerijos ${ }^{b}$. (2019). Lietuvoje mažèja apleistų žemių (National Land Service under the Ministry of Agriculture ${ }^{\mathrm{b}}$. The number of abandoned lands in Lithuania is decreasing), Viewed 27 december, 2019, (https://zis.lt/lietuvoje-mazeja-apleistu-zemiu/), (in Lithuanian).

11. www.delfi.lt. (6 june, 2019). Nustatè, kurioje savivaldybėje apleistų žemès sklypų daugiausia, kurioje mažiausia. (Determined which municipality had the highest number of brownfields and the smallest) Delfi. Viewed 25 december, 2019, (https:/www.delfi.lt/agro/agroverslo-naujienos/nustate-kurioje-savivaldybejeapleistu-zemes-sklypu-daugiausia-kurioje-maziausia.d?id=81385825), (in Lithuanian).

Information about authors:

Ruta, Puziene, doctor, associated professor, Institute of Land management and Geometics, Vytautas Magnus University Agriculture Academy, Studentų str. 11, LT-53361 Akademija, Kaunas distr., +37037 752 272, ruta.puziene@,vdu.lt. Fields of interest: Vertical earth crust movement's investigations, geographic information systems, surface modelling, geodetic measurement history.

Asta, Anikenienee, doctor, associated professor, Vilnius College of Technologies and Design, Civil Engineering Faculty, Department of Construction Engineering, Antakalnio s. 54, Vilnius, Lithuania, +370 61432520 , a.anikeniene@vtdko.lt, e-mail. Fields of interest: Vertical earth crust movement's investigations, territory planning, geographic information systems. 